\title{
Limited Genetic Diversity in North American Isolates of Phytophthora erythroseptica Pathogenic to Potato Based on RAPD Analysis
}

Rick D. Peters, Agriculture and Agri-Food Canada, Crops and Livestock Research Centre, 440 University Ave., Charlottetown, PEI C1A 4N6 Canada; Rod J. Clark, Albert D. Coffin, and Antony V. Sturz, PEI Dept. of Agriculture and Forestry, Plant Health Research \& Diagnostics, P.O. Box 1600, Charlottetown, PEI C1A 7N3 Canada; David H. Lambert, Dept. of Applied Ecology and Environmental Science, University of Maine, 5722 Deering Hall, Room 9, Orono, ME 04469-5722 U.S.A.; and Jeff S. Miller, University of Idaho, Dept. of Plant, Soil and Entomological Sciences, P.O. Box 870, Aberdeen, ID 83210-0870 U.S.A.

\begin{abstract}
Peters, R. D., Clark, R. J., Coffin, A. D., Sturz, A. V., Lambert, D. H., and Miller, J. S. 2005. Limited genetic diversity in North American isolates of Phytophthora erythroseptica pathogenic to potato based on RAPD analysis. Plant Dis. 89:380-384.

Pink rot of potato (Solanum tuberosum), caused by Phytophthora erythroseptica, is found wherever potatoes are grown, and in the last decade, it has reemerged as an economically important disease in Canada and the United States. A selection of isolates of P. erythroseptica from major potato-growing regions in North America, namely Prince Edward Island and New Brunswick, Canada, and Maine and Idaho, U.S.A., was assessed for genetic diversity with randomly chosen decanucleotide primers which were used to amplify regions of DNA to reveal polymorphisms among templates (random amplified polymorphic DNA [RAPD]). The isolates varied in their geographic origin as well as in their sensitivity to mefenoxam, as determined by an in vitro assay. In three separate RAPD screens (I, II, and III) with 23 isolates of $P$. erythroseptica chosen from a larger collection, 1,410, 369, and 316 robust, scorable bands were amplified, respectively. However, among the bands amplified in screens I, II, and III, only 3, 1, and 3 bands, respectively, were polymorphic. When three primers yielding polymorphisms were used to screen 106 isolates from Prince Edward Island and New Brunswick, or a representative collection of 32 isolates from Prince Edward Island, New Brunswick, Maine, and Idaho, no major variation was discovered. RAPD markers were not correlated with geographic origin or mefenoxam sensitivity of the isolates. From an evolutionary standpoint, the absence of genetic diversity among the isolates of $P$. erythroseptica we examined may be attributable to the relatively recent introduction of a small founding population of the pathogen in North America.
\end{abstract}

Phytophthora erythroseptica Pethyb. is an oomycete and therefore belongs to a group of organisms closely related to chromophyte algae, such as diatoms (9). Isolates of $P$. erythroseptica are diploid, homothallic (self-fertile; 17,42), and produce oospores that can survive for many years in soil (49).

Diversity within or among populations of $P$. erythroseptica has not been well documented. Strains of the pathogen specific to a particular plant species have been reported, including isolates pathogenic to potato (Solanum tuberosum L.; 34,35), raspberry (Rubus spp.; 3), tomato (Lycopersicon esculentum L.; 12), clover (Tri-

Corresponding author: R. D. Peters

E-mail: petersr@agr.gc.ca

AAFC Contribution No. 1037

Accepted for publication 12 November 2004.

DOI: 10.1094/PD-89-0380

This article is in the public domain and not copyrightable. It may be freely reprinted with customary crediting of the source. The American Phytopathological Society, 2005. folium spp.; 36), lupine (Lupinus spp.; 46), white calla (Zantedeschia aethiopica Spreng.; 44), and pea (Pisum sativum L.; 5). In addition, isolates of $P$. erythroseptica that are resistant to mefenoxam, a systemic fungicide generally used for suppression of diseases caused by oomycetes, have been recovered from various locations in the United States $(14,20,43)$.

Pink rot of potato is found in most major potato-growing regions of the world (48), and propagules of $P$. erythroseptica are endemic in almost all cultivated soils where potatoes are grown (21). Poorly drained land and warm, wet conditions at harvest tend to exacerbate disease incidence and severity (2,37). All underground potato tissues can become infected by $P$. erythroseptica. Root and stem infection can result in plant wilting and death, while tuber infection leads to pink rot development in the field and in storage.

The re-emergence of potato pink rot as an economically important disease has been partly fueled by the increase in occurrence of mefenoxam-resistant strains of the pathogen and the lack of disease-resistant potato cultivars. Mefenoxam (or its parent isomer metalaxyl) is a systemic fungicide commonly applied for control of potato diseases caused by oomycetes. Prior to the 1990 s, metalaxyl was routinely used prophylactically for the control of late blight caused by Phytophthora infestans (Mont.) de Bary. However, in the mid-1990s, metalaxyl-sensitive strains of $P$. infestans were displaced by migrant, resistant genotypes such as US-8 in the United States and Canada $(15,16,29,30)$, resulting in loss of fungicide utility. Even so, mefenoxam is still applied to the potato crop for the suppression of pathogens causing tuber rot diseases such as leak (causal agent: $P y$ thium ultimum var. ultimum Trow) and pink rot. In recent years, the recovery of mefenoxam-resistant strains of $P$. erythroseptica in the United States and Canada $(14,20,43)$ has created concern that successful control of pink rot also is in jeopardy.

Pathogen diversity can play a critical role in disease dynamics and, consequently, in the success of diseasemanagement strategies, including the development of cultivars resistant to pink rot. Random amplified polymorphic DNA (RAPD; 53) analysis has been used successfully to assess diversity among isolates of other Phytophthora species (6,23$25,27,50)$. Therefore, our aim was to assess the genetic diversity in collections of isolates of $P$. erythroseptica from North America pathogenic to potato using the RAPD method.

\section{MATERIALS AND METHODS}

Source of isolates. Tubers with symptoms of pink rot were collected from harvested fields and warehouses in Prince Edward Island and New Brunswick, Canada, during 1999 to 2001. Individual tubers were cut longitudinally, and small tissue samples $(10 \times 5 \times 3 \mathrm{~mm})$ were taken from the margins of necrotic regions with a sterile scalpel, surface-sterilized in $0.6 \%$ sodium hypochlorite for $30 \mathrm{~s}$, rinsed twice in sterile distilled water, and blotted dry on sterile filter paper (Whatman no. 4). Tissue pieces were then plated onto $1.5 \%$ water agar in small petri dishes $(60 \times 15 \mathrm{~mm})$. Petri dishes were incubated in the dark at $22^{\circ} \mathrm{C}$ for 3 to 4 days. Following incubation, hyphal tips from the margins of ac- 
tively growing cultures were removed with a sterile probe and plated onto clarified V8 medium (33) to generate pure cultures. In addition, pure cultures growing in agar medium were obtained from Maine and Idaho. The entire collection of isolates was comprised of 104 from Prince Edward Island, 2 from New Brunswick, 32 from Maine, and 30 from Idaho. All isolates were identified to the species level using the keys of Newhook et al. (26) and Gerrettson-Cornell (11). Isolates in pure culture were used to generate single-zoospore isolates using a protocol described previously (33).

Mefenoxam sensitivity of isolates. Single-zoospore isolates were characterized for mefenoxam sensitivity using clarified V8 medium amended with $0,0.5,1,5$, $10,50,100$, or $500 \mu \mathrm{g}$ of mefenoxam per $\mathrm{ml}$ as described in Peters et al. (33). Calculated $\mathrm{EC}_{50}$ values (the mefenoxam concentration inhibiting the growth of the pathogen by $50 \%$ ) were used to recognize three categories of sensitivity: sensitive $\left(\mathrm{S} ; \mathrm{EC}_{50}\right.$ $<1 \mu \mathrm{g} / \mathrm{ml}$ ), moderately resistant (MR; $\mathrm{EC}_{50}=1$ to $100 \mu \mathrm{g} / \mathrm{ml}$ ), and highly resis$\operatorname{tant}\left(\mathrm{HR} ; \mathrm{EC}_{50}>100 \mu \mathrm{g} / \mathrm{ml}\right)$.

Genomic DNA extraction. Agar plugs (5 $\mathrm{mm}$ diameter) taken from the margins of 3-day-old single-zoospore cultures of $P$. erythroseptica were placed in $15 \mathrm{ml}$ of clarified V8 broth (33) in 50-ml plastic disposable sterile centrifuge tubes to generate mycelium for DNA extraction. Tubes were placed in the dark at $18^{\circ} \mathrm{C}$ for 3 days to allow growth of the pathogen. Following incubation, the tubes were centrifuged at $5,000 \mathrm{rpm}(4,137 \times g)$ for $5 \mathrm{~min}$ to collect the mycelium. Excess V8 broth was decanted, and each mycelial pellet was then washed twice with sterile distilled water and centrifuged for a further $5 \mathrm{~min}$ at $5,000 \mathrm{rpm}(4,137 \times g)$. After decanting wash water, mycelial pellets were drawn up the side of the tube with a sterile spatula and pressed to remove excess water. Pellets were transferred to labeled $1.5-\mathrm{ml}$ centrifuge tubes and stored at $-80^{\circ} \mathrm{C}$ prior to DNA extraction.

DNA extraction was performed using the DNeasy Plant Mini Kit (Qiagen Inc. Canada, Mississauga, Ontario) according to the manufacturer's instructions. Sterile sea sand (autoclaved Fisher S25-500) was added to the mortar during grinding in liquid nitrogen to enhance tissue disruption. DNA absorbance was measured at 260 and $280 \mathrm{~nm}$ using a SmartSpec 3000 (Bio-Rad Laboratories (Canada) Ltd., Mississauga, Ontario) to determine extraction yields.

RAPD polymerase chain reaction (PCR). RAPD analysis of selected isolates of $P$. erythroseptica was performed in three separate screens. In screen I, 360 RAPD primers from Kits A, B, C, D, E, F, H, and $\mathrm{Y}$ (Operon Technologies, Inc., Alameda, CA) and UBC Sets 1 and 8 (University of British Columbia, Nucleic Acid-Protein
Service Unit, Vancouver, BC Canada) were used in reactions with DNA templates from four selected isolates of $P$. erythroseptica from Prince Edward Island and Maine (Table 1). These isolates originated from four fields in different regions within Prince Edward Island and Maine and also showed diversity for mefenoxam sensitivity (Table 1). Primers that revealed polymorphisms were then used to assess a larger collection of 106 single-zoospore isolates of $P$. erythroseptica from Prince Edward Island and New Brunswick, Canada. In screen II, 80 RAPD primers, chosen for their ability to produce reproducible banding patterns in screen I, were used in reactions with DNA templates from 10 selected isolates of $P$. erythroseptica from Prince Edward Island and New Brunswick, Canada (Table 1). Finally, in screen III, 60 RAPD primers, chosen for their ability to produce reproducible banding patterns in screens I and II, were used in reactions with DNA templates from 10 selected isolates of $P$. erythroseptica from Prince Edward Island, New Brunswick, Maine, and Idaho (Table 1). Again, these isolates originated from 10 fields representing different potato production areas of North America and also showed diversity for mefenoxam sensitivity (Table 1). Following screens I to III, the three primers (OPF 01, OPH 12, UBC 730) that consistently revealed polymorphisms were used to assess a representative collection of 32 single-zoospore isolates of $P$. erythroseptica from Prince Edward Island, New Brunswick, Maine, and Idaho.

Reactions were performed in $25-\mu \mathrm{l}$ volumes containing $1 \times$ buffer $(10 \mathrm{mM}$ Tris$\mathrm{HCl}, \mathrm{pH} 8.3,50 \mathrm{mM} \mathrm{KCL}, 2 \mathrm{mM} \mathrm{MgCl} 2$ ), $0.2 \mathrm{mM}$ dNTPs, $0.45 \mu \mathrm{M}$ primer, $1 \mathrm{U}$ of AmpliTaq DNA polymerase (PerkinElmer Life and Analytical Sciences, Woodbridge, Ontario), and $50 \mathrm{ng}$ of genomic DNA template. DNA amplification was performed in a DNA Engine (MJ Research, Inc., Waltham, MA) with an initial cycle at $94^{\circ} \mathrm{C}$ for $5 \mathrm{~min}, 33^{\circ} \mathrm{C}$ for $2 \mathrm{~min}$, and $72^{\circ} \mathrm{C}$ for $2 \mathrm{~min}$, followed by 35 cycles at $94^{\circ} \mathrm{C}$ for $1 \mathrm{~min}, 33^{\circ} \mathrm{C}$ for $1 \mathrm{~min}$, and $72^{\circ} \mathrm{C}$ for 2 min, and a final incubation at $72^{\circ} \mathrm{C}$ for 10 min. Reaction conditions were optimized for each primer individually to enhance the detection of polymorphic bands.

RAPD PCR products $(10 \mu \mathrm{l})$ were loaded into $1 \%$ agarose gels and run for 1 $\mathrm{h}$ at $90 \mathrm{~V}$. The gels were visualized with a UV light box after staining with SyberGreen nucleic acid gel stain (Molecular Probes, Inc., Eugene, OR), and the resulting images were then captured with a Kodak DC290 digital camera. Gel lanes were arranged so that templates with the same primer were run side by side to allow a quick visual assessment of RAPD patterns among isolates. All reactions were run twice to resolve questionable results or confirm polymorphisms. For each primer, nonreproducible fragments between the

Table 1. Number, source, and mefenoxam sensitivity of single-zoospore isolates of Phytophthora erythroseptica used in each of three random amplified polymorphic DNA (RAPD) screens

\begin{tabular}{|c|c|c|c|c|}
\hline Screen & Primers $^{a}$ & Isolates $^{\mathbf{b}}$ & $\begin{array}{l}\text { Isolate } \\
\text { source }^{c}\end{array}$ & $\begin{array}{l}\text { Mefenoxam } \\
\text { sensitivity }^{\mathrm{d}}\end{array}$ \\
\hline I & $\begin{array}{l}\text { OPA } 1-20 \text {, OPB } 1-20 \text {, OPC } 1-20 \text {, } \\
\text { OPD } 1-20 \text {, OPE } 1-20 \text {, OPF } 1-20 \text {, } \\
\text { OPH } 1-20 \text {, OPY } 1-20 \text {, } \\
\text { UBC } 1-100 \text {, UBC } 701-800\end{array}$ & $\begin{array}{l}\text { PE9909-1BSZ1 } \\
\text { PE9913-2ASZ1 } \\
\text { PE99C3SZ3 } \\
\text { PE99C5SZ3 }\end{array}$ & $\begin{array}{l}\mathrm{PE} \\
\mathrm{PE} \\
\mathrm{ME} \\
\mathrm{ME}\end{array}$ & $\begin{array}{c}\mathrm{S} \\
\mathrm{S} \\
\mathrm{S} \\
\mathrm{HR}\end{array}$ \\
\hline II & $\begin{array}{l}\text { OPA } 03,04,11,18,19 ; \text { OPB } 07,10,17 \text {; } \\
\text { OPC 02; OPD } 01,02,03,11,18 ; \\
\text { OPE } 08,09,15,16,19,20 ; \\
\text { OPF } 04,06,13,14,16 ; \\
\text { OPH } 02,03,04,12,13,19,20 ; \\
\text { OPY } 08,14,15,16,17,20 ; \\
\text { UBC } 29,38,51,60,71,72,75,77,79,82, \\
83,84,88,90,91,96,97,98,703,704, \\
710,712,714,718,726,727,728,729, \\
730,731,732,733,734,735,751, \\
754,755,770,778,790,791,798\end{array}$ & $\begin{array}{l}\text { PE9906-1BSZ2 } \\
\text { PE9910-1ASZ1 } \\
\text { PE9911-1ASZ2 } \\
\text { PE9915-1ASZ1 } \\
\text { PE9916-2ASZ1 } \\
\text { PE9924-1DSZ1 } \\
\text { PE9927-2CSZ1 } \\
\text { PE0104-10SZ2 } \\
\text { PE0105-SZ1 } \\
\text { PE0106-SZ1 }\end{array}$ & $\begin{array}{l}\text { PE } \\
\text { PE } \\
\text { PE } \\
\text { PE } \\
\text { PE } \\
\text { PE } \\
\text { PE } \\
\text { PE } \\
\text { NB } \\
\text { NB }\end{array}$ & $\begin{array}{l}\text { S } \\
S \\
S \\
S \\
S \\
S \\
S \\
S \\
S \\
S \\
S \\
S\end{array}$ \\
\hline III & $\begin{array}{l}\text { OPA } 03,04,11,18,19 ; \text { OPB } 07,10,17 \text {; } \\
\text { OPC 02; OPD 01,02,03,11,18; } \\
\text { OPE 08,09,15,19,20; OPF } 13,14,16 \text {; } \\
\text { OPH 02,03,04,13,19,20; } \\
\text { OPY 08,14,15, 16,20; } \\
\text { UBC } 60,72,75,79,82,83,84,90, \\
91,703,712,714,718,727,728,730 \\
731,732,733,734,751,755,770,778 \\
790,791,798\end{array}$ & $\begin{array}{l}\text { PE9910-1ASZ1 } \\
\text { PE0106-SZ2 } \\
\text { PE0201 } \\
\text { PE0210 } \\
\text { PE0221 } \\
\text { PE0227 } \\
\text { PE0237 } \\
\text { PE0242 } \\
\text { PE0248 } \\
\text { PE0260 }\end{array}$ & $\begin{array}{l}\text { PE } \\
\text { NB } \\
\text { ME } \\
\text { ME } \\
\text { ME } \\
\text { ME } \\
\text { ID } \\
\text { ID } \\
\text { ID } \\
\text { ID }\end{array}$ & $\begin{array}{l}S \\
S \\
S \\
S \\
\text { HR } \\
\text { HR } \\
\text { S } \\
\text { S } \\
\text { HR } \\
\text { HR }\end{array}$ \\
\hline
\end{tabular}

${ }^{\mathrm{a}} \mathrm{OP}=$ Operon Technologies, Inc., Alameda, CA; UBC = University of British Columbia, Nucleic Acid-Protein Service Unit, Vancouver, BC Canada.

${ }^{b}$ Isolate codes in the culture collection housed in Agriculture and Agri-Food Canada, Crops and Livestock Research Centre, Charlottetown, PEI, Canada.

${ }^{\mathrm{c}} \mathrm{PE}=$ Prince Edward Island, Canada; $\mathrm{NB}=$ New Brunswick, Canada; $\mathrm{ME}=$ Maine, U.S.A.; ID = Idaho, U.S.A.

${ }^{\mathrm{d}} \mathrm{S}=$ sensitive; $\mathrm{HR}=$ highly resistant. 
repeated tests were disregarded. Comparison of profiles for each primer was done on the basis of the presence or absence of RAPD fragments presumed to be the same length and scored as identical.

\section{RESULTS AND DISCUSSION}

All isolates of $P$. erythroseptica from Prince Edward Island and New Brunswick were sensitive to mefenoxam, whereas isolates from Maine and Idaho were either sensitive or highly resistant.

Visualization of randomly amplified PCR products revealed clear banding patterns that were reproducible (Fig. 1). In screen I, using DNA templates of isolates from Prince Edward Island and Maine, 293 of 360 random primers yielded a total of 1,410 scorable bands (Table 2). Somewhat surprisingly, only three bands were polymorphic. This minor variation was insufficient for further meaningful population analysis and did not correlate with isolate source or mefenoxam sensitivity. Nevertheless, the three RAPD markers were used to assess a larger collection of singlezoospore isolates from Prince Edward Island (104 isolates) and New Brunswick (2 isolates). Again, only minor variation was found (two haplotypes) with primer OPF 01 (Fig. 1) that distinguished several isolates from one tuber from one field (a polymorphic fragment of $\sim 1,500$ bp was absent in 8 isolates from this field and present in 7 isolates from this field).

To examine a greater range of DNA templates with a large primer set (screen II), 10 isolates of $P$. erythroseptica recovered from individual fields from across Prince Edward Island (8 isolates) and New Brunswick (2 isolates) were screened with 80 primers chosen from screen I for their ability to produce clear, reproducible banding patterns (Table 1). A total of 369 scorable bands was amplified, but only one was polymorphic (Table 2 ).

A final screen (screen III) was conducted with DNA templates from isolates of $P$. erythroseptica from different geographic locations including Prince Edward
Island, New Brunswick, Maine, and Idaho, and that showed diversity in sensitivity to mefenoxam (Table 1). Sixty primers chosen from screens I and II for their ability to produce clear, reproducible banding patterns (Table 1) amplified a total of 316 scorable bands, of which only 3 were polymorphic RAPD markers (Table 2). Again, this minor variation was insufficient for further meaningful population analysis and did not correlate with isolate source or mefenoxam sensitivity. Even so, the three RAPD markers were used to assess a representative collection of 32 single-zoospore isolates from Prince Edward Island (16 isolates), New Brunswick (2 isolates), Maine (6 isolates), and Idaho (8 isolates). Again, only minor variation was found (Table 3).

At the start of this study, our intent was to identify a series of primers and RAPD markers that could then be used to assess a large collection of single-zoospore isolates from geographically diverse potato grow- ing regions in North America. As these collections included isolates differing in mefenoxam sensitivity, it was hoped that an RAPD marker to detect this trait would be found. However, only very minor genetic variation was revealed by RAPD screening of representative isolates, and this variation was not correlated with isolate source or mefenoxam sensitivity. This is somewhat surprising given the ease with which RAPD markers are generally found in screens with DNA templates of other Phytophthora species. For example, in heterothallic species, 9 random decanucleotide primers amplified 217 polymorphic bands in a collection of isolates of $P$. cinnamomi Rands from Taiwan (6), 16 RAPD markers were generated from 4 random decanucleotide primers used to amplify regions of DNA from collections of $P$. cinnamomi from South Africa and Australia (23), 9 Operon primers chosen from a screen of 40 primers for reliability and polymorphism revealed 33 polymor-

Table 2. Summary of the results of three random amplified polymorphic DNA (RAPD) primer screens using isolates of Phytophthora erythroseptica obtained from Prince Edward Island and New Brunswick, Canada, and Maine and Idaho, U.S.A.

\begin{tabular}{|c|c|c|c|}
\hline & Screen I & Screen II & Screen III \\
\hline Number of isolates & 4 & 10 & 10 \\
\hline Number of primers assessed & 360 & 80 & 60 \\
\hline $\begin{array}{l}\text { Number of primers yielding amplified } \\
\text { polymerase chain reaction products }\end{array}$ & 293 & 80 & 60 \\
\hline Total number of amplified bands & 1,410 & 369 & 316 \\
\hline $\begin{array}{l}\text { Number of polymorphic bands (RAPD } \\
\text { markers) }\end{array}$ & 3 & 1 & 3 \\
\hline
\end{tabular}

Table 3. Polymorphic loci and number of random amplified polymorphic DNA (RAPD) haplotypes detected by each primer among 32 isolates of Phytophthora erythroseptica from Prince Edward Island, New Brunswick, Maine, and Idaho

\begin{tabular}{lcccc}
\hline Primers $^{\mathbf{a}}$ & Primer sequences & $\begin{array}{c}\text { Total number of } \\
\text { bands amplified }\end{array}$ & $\begin{array}{c}\text { Number of } \\
\text { polymorphic markers }\end{array}$ & $\begin{array}{c}\text { RAPD } \\
\text { haplotypes }\end{array}$ \\
\hline OPF 01 & 5'-ACGGATCCTG & 3 & 1 & 2 \\
OPH 12 & 5'-ACGCGCATGT & 8 & 1 & 2 \\
UBC 730 & 5'-CCACACCCAC & 5 & 1 & 2 \\
Total & & 16 & 3 & \\
\hline
\end{tabular}

a $\mathrm{OP}=$ Operon Technologies, Inc., Alameda, CA; UBC = University of British Columbia, Nucleic Acid-Protein Service Unit, Vancouver, BC Canada.

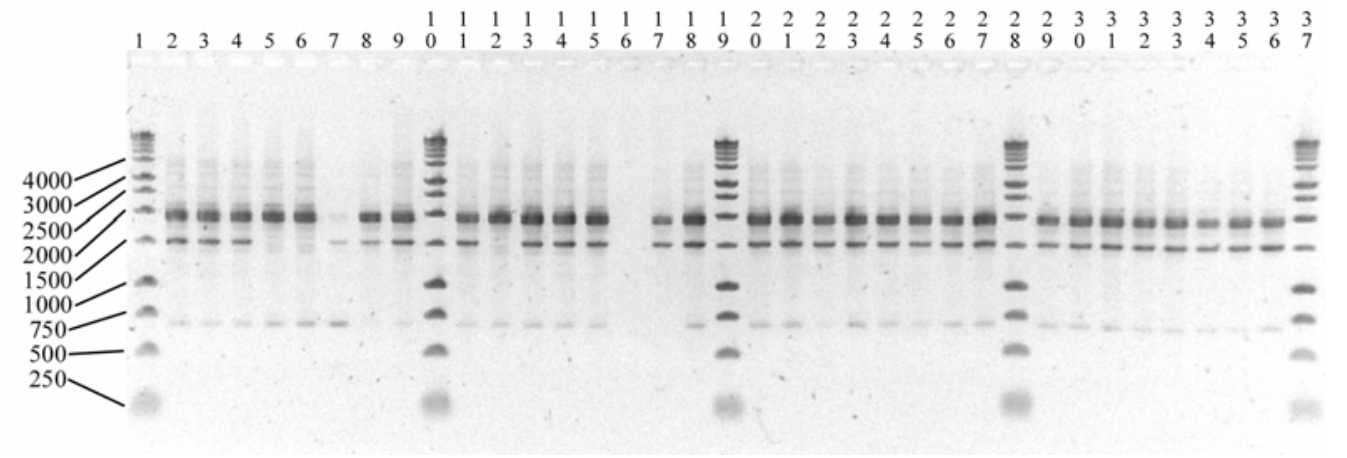

Fig. 1. Phytophthora erythroseptica isolates from Prince Edward Island assayed with Operon Primer F01 revealing polymorphic patterns. A total of $10 \mu \mathrm{l}$ of each polymerase chain reaction (PCR) product was loaded per lane on a $1 \%$ agarose gel. They were loaded in sequential order with the exception of lanes 1 , $10,19,28$, and 37, which contained marker DNA. Lanes 5, 6, and 12 are missing the band of interest at $\sim 1,500 \mathrm{bp}$. Reactions from lanes 7 and 16 were rerun and assessed on another gel. 
phic amplified products in a collection of isolates of $P$. megakarya Brasier \& M.J. Griffin (27), and 6 Operon primers chosen from a screen of 40 primers for reliability and polymorphism revealed 77 polymorphic markers in a collection of isolates of $P$. infestans (Mont.) de Bary (24). In $P$. sojae Kaufm. \& Gerd., a homothallic species similar to $P$. erythroseptica (18), a screen of 220 decanucleotide primers revealed 16 that detected polymorphisms and yielded 23 polymorphic fragments in a collection of isolates from the United States (25). In a similar study of $P$. sojae isolates collected from China, 13 decanucleotide primers revealed 68 polymorphic RAPD markers (50).

The genetics of mefenoxam resistance in $P$. erythroseptica are still unclear. Studies with $P$. infestans have suggested that resistance to mefenoxam (metalaxyl) is governed by a single nuclear locus exhibiting incomplete dominance (40), and a similar hypothesis was put forward by Goodwin and McGrath (14) to explain metalaxyl resistance in $P$. erythroseptica and the origin of a class of isolates that were intermediate in resistance. However, more recent work with $P$. infestans has provided contrasting evidence, including reports that metalaxyl resistance is conferred by a single dominant gene with minor genes causing variation in isolate response (22), or that resistance is governed by at least two major loci with other minor loci contributing additive effects $(8,19)$. The wide range of metalaxyl sensitivity found in a large collection of Canadian isolates of the US- 8 genotype of $P$. infestans classed as moderately resistant implied that more than one gene was involved in phenotypic expression (polygenic control; 29). This may also be the case for $P$. erythroseptica, but the occurrence of this intermediate form seems to be relatively rare, as isolates in this class comprised only $5 \%$ of 805 isolates collected from 1997 to 2000 in the United States (43). RAPD markers have been linked to metalaxyl insensitivity loci in $P$. infestans (8). Unfortunately, we were unable to find a RAPD marker that correlated with mefenoxam sensitivity in our collection of isolates. Such a marker would be a useful tool in the on-going effort to monitor the spread of mefenoxam-resistant strains of $P$. erythroseptica in North America.

Host specificity has generally been used to separate strains of $P$. erythroseptica. However, isolates of $P$. erythroseptica pathogenic to potato have also caused disease in tomato, spinach, and tulip (21). In addition, isolates pathogenic to potato have been recovered from the asymptomatic roots of several nonsolanaceous hosts, including wheat and rye (51). Although commercial potato cultivars vary in susceptibility to pink rot $(32,38)$, none is immune to disease, and the type of race- specific resistance that has been well documented for other oomycete-host interactions, including $P$. sojae-soybean (4) and $P$. infestans-potato (1), has not been reported for $P$. erythroseptica-potato interactions. Indeed, studies examining potato host response to pathogen attack have uncovered no pathogenic diversity among isolates used for inoculation $(31,32,38,41)$. These reports of the lack of pathogenic diversity among potato-infecting strains of $P$. erythroseptica are consistent with our general findings of low diversity in the pathogen genome as a whole.

In the field, $P$. erythroseptica has an active sexual cycle, and so individual isolates are most likely to be extensively homozygous as a result of repeated selfing, as has been found for isolates of the homothallic $P$. sojae $(10,47)$. Variation, such as at loci conferring resistance to mefenoxam, would be generated mainly by mutation. In addition, migration of strains in infected seed tubers (7) may introduce new genotypes into a growing region. Outcrossing has been found to play a significant role in the generation of genetic variation in other homothallic oomycetes including Aphanomyces euteiches Drechs. (39) and P. sojae $(10,47,52)$. Outcrossing has, as yet, never been demonstrated experimentally between isolates of $P$. erythroseptica, and so its impact on pathogen populations is unknown.

From an evolutionary standpoint, the absence of genetic diversity among the isolates of P. erythroseptica we examined may be attributable to the relatively recent introduction of a small founding population of the pathogen in North America. Pink rot of potato was first described in Ireland by Pethybridge in 1913 (34) and was initially reported in the United States in Maine in 1938 (2). The heterothallic $P$. infestans apparently evolved in the highlands of central Mexico, and it is here that sexual reproduction and the most genetic diversity among isolates is found (45). Genetic variation in clonal A1 (US-1) North American populations of $P$. infestans was most likely generated only by mutation and asexual processes such as mitotic recombination in the absence of sexual reproduction with the opposite $\mathrm{A} 2$ mating type (13), prior to the migration of A2 strains into Canada and the United States in the 1990s (15). Even so, these processes were sufficient to generate a number of physiologic races of the pathogen (28). In contrast, the evolutionary origin of $P$. erythroseptica is unknown, but migration via infected plant tissues, particularly seed tubers (7), has likely contributed to the pan-global distribution of strains pathogenic to potato.

\section{ACKNOWLEDGMENTS}

We thank the PEI Potato Board, PEI Potato Producers Association, Agriculture Research Investment Fund (ARIF), PEI Dept. of Agriculture and Forestry and Agriculture and Agri-Food Canada for financial contributions. We also thank Marleen Clark, Brian Matheson, Kathy MacIsaac, Ian Macdonald, and Carol Banks for technical assistance.

\section{LITERATURE CITED}

1. Black, W., Mastenbroek, C., Mills, W. R., and Peterson, L. C. 1953. A proposal for an international nomenclature of races of Phytophthora infestans and of genes controlling immunity in Solanum demissum derivatives. Euphytica 2:173-178.

2. Bonde, R. 1938. The occurrence of pink-rot and wilt in Maine. Plant Dis. Rep. 22:460.

3. Bristow, P. R., Daubeny, H. A., Sjulin, T. M., Pepin, H. S., Nestby, R., and Windom, G. E. 1988. Evaluation of Rubus germplasm for reaction to root rot caused by Phytophthora erythroseptica. J. Am. Soc. Hortic. Sci. 113:588-591.

4. Buzzell, R. I., Anderson, T. R., and Rennie, B. D. 1987. Harosoy Rps isolines. Soybean Genet. Newsl. 14:79-81.

5. Bywater, J., and Hickman, C. J. 1959. A new variety of Phytophthora erythroseptica, which causes a soft rot of pea roots. Trans. Br. Mycol. Soc. 42:513-524.

6. Chang, T. T., Yang, W. W., and Wang, W. Y. 1996. Use of random amplified polymorphic DNA markers for the detection of genetic variation in Phytophthora cinnamomi in Taiwan. Bot. Bull. Acad. Sin. 37:165-171.

7. Cunliffe, C., Lonsdale, D., and Epton, H. A. S. 1977. Transmission of Phytophthora eryth roseptica on stored potatoes. Trans. Br. Mycol. Soc. 69:27-30.

8. Fabritius, A.-L., Shattock, R. C., and Judelson, H. S. 1997. Genetic analysis of metalaxyl insensitivity loci in Phytophthora infestans using linked DNA markers. Phytopathology 87:1034-1040.

9. Förster, H., Coffey, M. D., Elwood, H., and Sogin, M. L. 1990. Sequence analysis of the small subunit ribosomal RNAs of 3 zoosporic fungi and implications for fungal evolution. Mycologia 82:306-312.

10. Förster, H., Tyler, B. M., and Coffey, M. D. 1994. Phytophthora sojae races have arisen by clonal evolution and by rare outcrosses. Mol. Plant-Microbe Interact. 7:780-791.

11. Gerrettson-Cornell, L. 1985. A working key to the species of Phytophthora de Bary. Acta Bot. Hung. 31:89-97.

12. Gillings, M. R., and Letham, D. B. 1989 Phytophthora erythroseptica causing wilting and stunting of tomato. Australas. Plant Pathol. 18:3-5.

13. Goodwin, S. B., Cohen, B. A., and Fry, W. E. 1994. Panglobal distribution of a single clonal lineage of the Irish potato famine fungus. Proc. Natl. Acad. Sci. USA 91:11591-11595.

14. Goodwin, S. B., and McGrath, M. T. 1995. Insensitivity to metalaxyl among isolates of Phytophthora erythroseptica causing pink rot of potato in New York. Plant Dis. 79:967.

15. Goodwin, S. B., Smart, C. D., Sandrock, R. W., Deahl, K. L., Punja, Z. K., and Fry, W. E. 1998. Genetic change within populations of Phytophthora infestans in the United States and Canada during 1994 to 1996: Role of migration and recombination. Phytopathology 88:939-949

16. Goodwin, S. B., Sujkowski, L. S., and Fry, W. E. 1996. Widespread distribution and probable origin of resistance to metalaxyl in clonal genotypes of Phytophthora infestans in the United States and western Canada. Phytopathology 86:793-800.

17. Ho, H. H., and Jong, S. C. 1989. Phytophthora erythroseptica. Mycotaxon 36:73-90.

18. Hong, S., Jee, H., Lee, S., and Go, S. 1999. Restriction fragment length polymorphism of PCR amplified ribosomal DNA among Korean isolates of Phytophthora. Plant Pathol. J. 15:228-235. 
19. Judelson, H. S., and Roberts, S. 1999. Multiple loci determining insensitivity to phenylamide fungicides in Phytophthora infestans. Phytopathology 89:754-760.

20. Lambert, D. H., and Salas, B. 1994. Metalaxyl insensitivity of Phytophthora erythroseptica isolates causing pink rot of potato in Maine. Plant Dis. 78:1010.

21. Lambert, D. H., and Salas, B. 2001. Pink rot. Pages 33-34 in: Compendium of Potato Diseases. W. R. Stevenson, R. Loria, G. D. Franc, and D. P. Weingartner, eds. American Phytopathological Society, St. Paul, MN.

22. Lee, T. Y., Mizubuti, E., and Fry, W. E. 1999. Genetics of metalaxyl resistance in Phytophthora infestans. Fungal Genet. Biol. 26:118-130.

23. Linde, C., Drenth, A., and Wingfield, M. J. 1999. Gene and genotypic diversity of Phytophthora cinnamomi in South Africa and Australia revealed by DNA polymorphisms. Eur. J. Plant Pathol. 105:667-680.

24. Mahuku, G. S., Peters, R. D., Platt, H. W. (Bud), and Daayf, F. 2000. Random amplified polymorphic DNA (RAPD) analysis of Phytophthora infestans isolates collected in Canada during 1994 to 1996. Plant Pathol. 49:252-260.

25. Meng, X. Q., Shoemaker, R. C., and Yang, X. B. 1999. Analysis of pathogenicity and genetic variation among Phytophthora sojae isolates using RAPD. Mycol. Res. 103:173-178.

26. Newhook, F. J., Waterhouse, G. M., and Stamps, D. J. 1978. Tabular key to the species of Phytophthora de Bary. Mycological Papers, No. 143. Commonwealth Mycological Institute, Kew, Surrey, England.

27. Nyassé, S., Grivet, L., Risterucci, A. M. Blaha, G., Berry, D., Lanaud, C., and Despréaux, D. 1999. Diversity of Phytophthora megasperma in Central and West Africa revealed by isozyme and RAPD markers. Mycol. Res. 103:1225-1234.

28. Peters, R. D., Platt, H. W. (Bud), and Hall, R. 1998. Changes in race structure of Canadian populations of Phytophthora infestans based on specific virulence to selected potato clones. Potato Res. 41:355-370.

29. Peters, R. D., Platt, H. W. (Bud), and Hall, R. 1998. Characterization of changes in populations of Phytophthora infestans in Canada using mating type and metalaxyl sensitivity markers. Can. J. Plant Pathol. 20:259-273.

30. Peters, R. D., Platt, H. W. (Bud), and Hall, R. 1999. Use of allozyme markers to determine genotypes of Phytophthora infestans in Canada. Can. J. Plant Pathol. 21:144-153.

31. Peters, R. D., and Sturz, A. V. 2001. A rapid technique for the evaluation of potato germ plasm for susceptibility to pink rot. Plant Dis. 85:833-837.

32. Peters, R. D., Sturz, A. V., and Arsenault, W. J. 2004. Tuber response of six potato cultivars to inoculation with Phytophthora erythroseptica Pethyb., the causal agent of pink rot disease. Can. J. Plant Pathol. 26:63-69.

33. Peters, R. D., Sturz, A. V., Matheson, B. G., Arsenault, W. J., and Malone, A. 2001. Metalaxyl sensitivity of isolates of Phytophthora erythroseptica in Prince Edward Island. Plant Pathol. 50:302-309.

34. Pethybridge, G. H. 1913. On the rotting of potato tubers by a new species of Phytophthora. Sci. Proc. Roy. Dub. Soc. 13:529565.

35. Pethybridge, G. H. 1914. Further observations on Phytophthora erythroseptica Pethyb. and on disease produced by it in the potato plant. Sci. Proc. Roy. Dub. Soc. 14:179-198.

36. Pratt, R. G. 1981. Morphology, pathogenicity, and host range of Phytophthora megasperma, $P$. erythroseptica, and $P$. parasitica from arrowleaf clover. Phytopathology 71:276-282.

37. Rowe, R. C., and Nielsen, L. W. 1986. Pink rot. Pages 39-40 in: Compendium of Potato Diseases. W. J. Hooker, ed. American Phytopathological Society, St. Paul, MN.

38. Salas, B., Secor, G. A., Taylor, R. J., and Gudmestad, N. C. 2003. Assessment of resistance of tubers of potato cultivars to Phytophthora erythroseptica and Pythium ultimum. Plant Dis. 87:91-97.

39. Shang, H., Grau, C. R., and Peters, R. D. 2000 Evidence of gene flow between pea and bean pathotypes of Aphanomyces euteiches. Can. J. Plant Pathol. 22:265-275.

40. Shattock, R. C. 1988. Studies on the inheritance of resistance to metalaxyl in Phytophthora infestans. Plant Pathol. 37:4-11.

41. Stack, R. W., Salas, B., Gudmestad, N. C., and Secor, G. A. 1992. Occurrence and distribution of potato pink rot, caused by Phytophthora erythroseptica. (Abstr.) Phytopathology 82:1138.
42. Stamps, D. J. 1978. Phytophthora erythrosep tica. Descriptions of Pathogenic Fungi and Bacteria, no. 593. Commonwealth Mycological Institute, Kew, Surrey, England.

43. Taylor, R. J., Salas, B., Secor, G. A., Rivera, V., and Gudmestad, N. C. 2002. Sensitivity of North American isolates of Phytophthora erythroseptica and Pythium ultimum to me fenoxam (metalaxyl). Plant Dis. 86:797-802.

44. Tompkins, C. M., and Tucker, C. M. 1950 Rhizome rot of white calla caused by $P h y$ tophthora erythroseptica. Phytopathology 40:712-714.

45. Tooley, P. W., Fry, W. E., and Villarreal Gonzalez, M. J. 1985. Isozyme characterization of sexual and asexual Phytophthora infestans populations. J. Hered. 76:431-435.

46. Trapero-Casas, A., Rodríguez-Tello, A., and Kaiser, W. J. 2000. Lupins, a new host of Phy tophthora erythroseptica. Plant Dis. 84:488.

47. Tyler, B. M., Förster, H., and Coffey, M. D 1995. Inheritance of avirulence factors and restriction fragment length polymorphism mark ers in outcrosses of the Oomycete Phytophthora sojae. Mol. Plant-Microbe Interact. 8:515-523.

48. Vargas, L. A., and Nielsen, L. W. 1972. Phytophthora erythroseptica in Peru: Its identification and pathogenesis. Am. Potato J. 49:309320.

49. Vujičić, R., and Park, D. 1964. Behaviour of Phytophthora erythroseptica in soil. Trans. $\mathrm{Br}$. Mycol. Soc. 47:455-458.

50. Wang, H., Wang, X., and Zhu, Z. 2003. Analysis of genetic diversity of Phytophthora sojae isolates in China using RAPD. Mycosystema 22:219-227.

51. Whelan, J., and Loughnane, J. B. 1969. Nonsolanaceous hosts of Phytophthora erythroseptica. Sci. Proc. Royal Dub. Soc., Ser. B. 2:171 178.

52. Whisson, S. C., Drenth, A., Maclean, D. J., and Irwin, J. A. G. 1994. Evidence for outcrossing in Phytophthora sojae and linkage of a DNA marker to two avirulence genes. Curr. Genet. 27:77-82

53. Williams, J. G. K., Kubelik, A. R., Livak, K. J., Rafalski, J. A., and Tingey, S. V. 1990. DNA polymorphisms amplified by arbitrary primers are useful as genetic markers. Nucleic Acids Res. 18:6531-6535. 